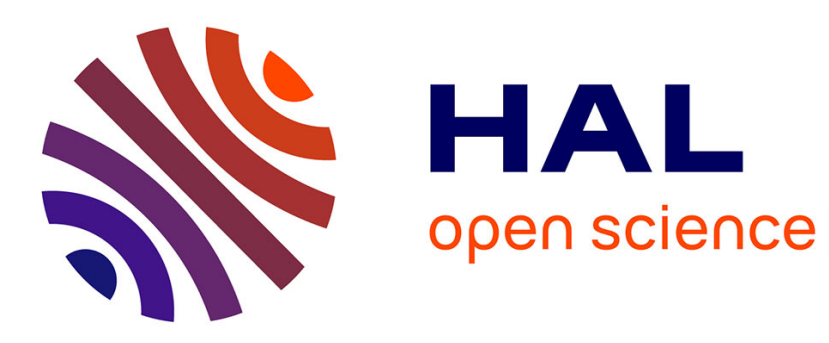

\title{
Portlandite solubility and Ca $2+$ activity in presence of gluconate and hexitols
}

\author{
Lina Bouzouaid, Barbara Lothenbach, A Fernandez-Martinez, Christophe \\ Labbez
}

\section{- To cite this version:}

Lina Bouzouaid, Barbara Lothenbach, A Fernandez-Martinez, Christophe Labbez. Portlandite solubility and Ca 2+ activity in presence of gluconate and hexitols. Cement and Concrete Research, 2021, 140, pp.106304. 10.1016/j.cemconres.2020.106304 . hal-03370261

\section{HAL Id: hal-03370261 \\ https://hal.science/hal-03370261}

Submitted on 7 Oct 2021

HAL is a multi-disciplinary open access archive for the deposit and dissemination of scientific research documents, whether they are published or not. The documents may come from teaching and research institutions in France or abroad, or from public or private research centers.
L'archive ouverte pluridisciplinaire HAL, est destinée au dépôt et à la diffusion de documents scientifiques de niveau recherche, publiés ou non, émanant des établissements d'enseignement et de recherche français ou étrangers, des laboratoires publics ou privés. 


\section{presence of gluconate and hexitols}

BOUZOUAID Lina ${ }^{1}$, LOTHENBACH Barbara ${ }^{2}$, FERNANDEZ-MARTINEZ Alejandro ${ }^{3}$, LABBEZ Christophe ${ }^{1}$

${ }^{1}$ ICB, UMR 6303 CNRS, Univ. Bourgogne Franche-Comté, FR-21000 Dijon, France

${ }^{2}$ Empa, Concrete \& Asphalt Laboratory, Dubendorf, Switzerland

${ }^{3}$ Univ. Grenoble Alpes, Univ. Savoie Mont Blanc, CNRS, IRD, IFSTTAR, ISTerre, 38000 Grenoble, France.

\section{Abstract}

The current paper investigates the impact of gluconate, D-sorbitol, D-mannitol and D-galactitol on calcium speciation at high $\mathrm{pH}$ values by i) solubility measurements of portlandite $\left(\mathrm{Ca}(\mathrm{OH})_{2}\right)$ and ii) potentiometric titration measurements of calcium salt solutions. Thermodynamic modeling was used to fit the chemical activities of $\mathrm{Ca}^{2+}$ and $\mathrm{OH}^{-}$ions and thus to determine the strength and kind of the different Ca-organic-hydroxide complexes. The strength of complex formation with $\mathrm{Ca}$ decreases in the order gluconate $>>$ sorbitol $>$ mannitol $>$ galactitol, which follows the same order as sorption on portlandite. Heteropolynuclear gluconate complexes with calcium and hydroxide dominate the Ca-speciation in the presence of portlandite, while for sorbitol ternary $\mathrm{CaSorbOH}^{+}$ complexes were dominant under alkaline conditions. We expect that these results will help in better understanding the influence of gluconate and hexitols on the hydration of alite and Portland cement.

1. Introduction

2 The chemical activity of ions, $a$, and the solubility of minerals are crucial factors in determining the 3 thermodynamic conditions and the driving force of a mineral to dissolve or to precipitate (1). The extent to which a solution is out of equilibrium is given by the deviation from the theoretical 
solubility and is quantified by the saturation index. For a solid such as portlandite, $\mathrm{Ca}(\mathrm{OH})_{2}$, with the solubility product $K_{s p, P o r t}$, the saturation index (SI) is defined as:

$$
\text { SIlog } 10=a_{\mathrm{Ca} 2+. a_{\mathrm{OH}-}{ }_{2} / K_{\text {Sp,port }}}
$$

The knowledge of the elemental concentrations, the speciation and the ion activities provides a simple measure for the driving force of dissolution or precipitation reactions. However, activity of ions is sensitive to the presence of other chemical species via the effect of ionic strength. Many ions can also form different soluble complexes such as e.g. calcium gluconate complexes: Cagluc ${ }^{+}$, $\mathrm{Ca}($ gluc $){ }_{2}{ }^{0}, \ldots$ and can in addition promote or inhibit crystal growth/dissolution, which can make the determination of the activity of ions difficult and tedious.

In the case of concrete, organic molecule inhibitors, called retarders, are commonly used in specific applications (2) (3) (4) to delay the cement setting. Superplasticizers, often comb co-polymers, employed in the formulation of ultra high performance concrete, are also known to retard the curing of concrete (5) (6) (7). Although used in low amount, less than 1 wt.\% of Portland cement (8), the concentration of organic molecules in the solution present in the interstitial pores formed by cement grains, easily reaches several tens of millimolar concentrations during the first hours after mixing with water and can thus impact the cement reactions involved in the curing. These effects have been illustrated in several studies with various organic molecules (9) (10). Invariably, it was found that the organic molecules acting as cement curing inhibitors can greatly influence the elemental concentrations in the aqueous pore solution and retard the cement hydration. The cement hydration is complex and dependent on two interrelated and concomitant processes, which are the dissolution of the cement grains and the precipitation of the hydrates. However, the physical and chemical mechanisms responsible for this retardation are not fully understood (11) (12) (13) (14) (15). Furthermore, in those organic-cement systems, an accurate quantification of the dissolution rate of cement anhydrates and precipitation rate of cement hydrates at well-defined $S I$ is still missing as a result of limited knowledge of complex formation. 
For the organics of interest in this paper, the pure dissolution of alite $\left(\mathrm{Ca}_{3} \mathrm{SiO}_{5}\right)$ was found to be negligibly affected by gluconate and three different hexitols, namely sorbitol, mannitol and galactitol (15). These organics, however, have a great impact on alite hydration and to a less extend on the hydration of Portland cement (15). These molecules were thus conjectured to mostly act as nucleation-growth inhibitors of calcium silicate hydrate, C-S-H (16) In a recent experimental study, it was suggested that the inhibition of the crystallization of portlandite, $\mathrm{Ca}(\mathrm{OH})_{2}$, could be the main reason of the slowdown of alite hydration (17).

Gluconate, a negatively charged molecule, was found to be a stronger retardant of cement hydration than neutral hexitols (16) (18) (19). For different hexitols also the stereochemical arrangements of the organic molecules, as illustrated in Figure 1, has an influence (16). The retardation was observed to increase from mannitol to galactitol to sorbitol, which have the same chemical composition and functional groups, but a different arrangement. However, the chemical mechanisms, which could explain how these organics retard are poorly understood, e.g. their impact on the anhydrate and hydrate solubility and the eventual formation of aqueous complexes [ (16) (18)]. In particular, in the high $\mathrm{pH}$ range little is known about possible aqueous complexes with organic molecules or their stability.

66

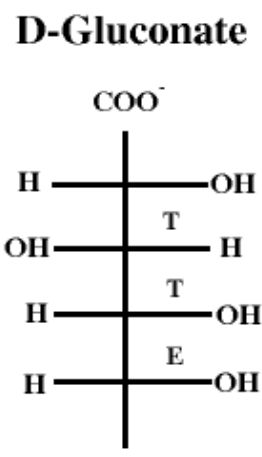

$\mathrm{CH}_{2} \mathrm{OH}$

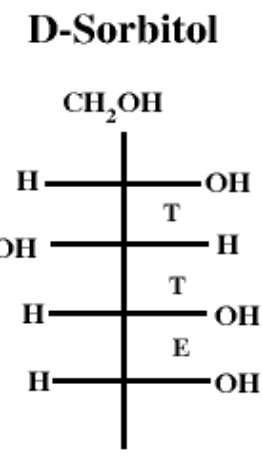

$\mathrm{CH}_{2} \mathrm{OH}$

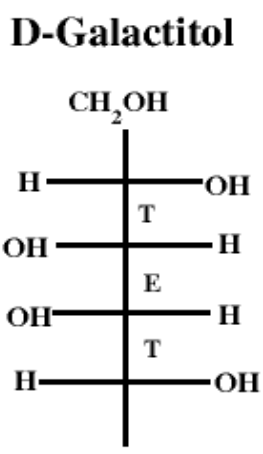

$\mathrm{CH}_{2} \mathrm{OH}$

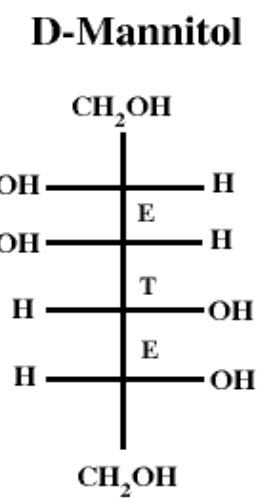

$\mathrm{CH}_{2} \mathrm{OH}$

73 Figure 1: Structure of (from left to right) D-gluconate, D-sorbitol, D-galactitol and D-mannitol. "T" 74 corresponds to the threo diastereoisomer configuration. "E" corresponds to erythro diastereoisomer 75 configuration. 
77 It has been suggested that the ability of the organic molecules to form complexes with $\mathrm{Ca}^{2+}$ is directly correlated to their adsorption affinity with calcium rich surfaces of C-S-H and alite (18) (19) which, in turn, may impart the surface tension of the nucleus or the rate of attachment of species to the nucleus and, thus, the nucleation rate. Thus, the understanding and quantification of complex formation between organic molecules and calcium could be fundamental for a better understanding of the observed retardation by organic additives ${ }^{1}$. In addition, only an adequate quantification of the different $\mathrm{Ca}$-complexes formed in the presence of organics makes it possible to determine the ion activities needed to calculate $S I$ with respect to $\mathrm{Ca}_{3} \mathrm{SiO}_{5}$, calcium silicate hydrate and portlandite.

D-gluconate, is a well know retarding additive (20) (21) (22) widely used in the industry. In addition to its role as retarder in cements and concretes, gluconate is also used for water treatment and metal surface treatment due its strong complexation ability with cations. The complex formation between Ca and gluconate has been investigated in several studies (23) (24) (25) (26) (27) (28), but mainly at high ionic strength $(1.0 \mathrm{M} \mathrm{NaCl})$ and relatively low $\mathrm{pH}$. On the other hand, the complex formation between hexitols and calcium ions was much less investigated (29) (30) and again at relatively low $\mathrm{pH}$ values not relevant for cements. The present paper thus aims to investigate the speciation of alkaline calcium solutions in the presence of a carboxylate sugar acid: gluconate and several uncharged hexitols: D-sorbitol (Dmeasurements of alkaline calcium solutions in presence of increasing amount of organics. The results were then fitted with a speciation model, using the open source software PHREEQC, to determine the strength and the various types of calcium complexes with the organic molecules. 


\section{Materials and methods}

104

105

106

107

108

109

110

111

112

113

\subsection{Materials}

The different stock solutions from each compound were prepared by dissolving $\mathrm{Ca}\left(\mathrm{NO}_{3}\right)_{2} 4 \mathrm{H}_{2} \mathrm{O}$ (Sigma-Aldrich, $\geq 99 \%$ purity), potassium gluconate $\left(\mathrm{C}_{6} \mathrm{H}_{11} \mathrm{KO}_{7}\right.$, Sigma-Aldrich, $\geq 99 \%$ purity) Dsorbitol $\left(\mathrm{C}_{6} \mathrm{H}_{14} \mathrm{O}_{6}\right.$, Sigma-Aldrich, $\geq 99 \%$ purity), D-mannitol $\left(\mathrm{C}_{6} \mathrm{H}_{14} \mathrm{O}_{6}\right.$, Sigma-Aldrich, $\geq 99 \%$ purity), and D-galactitol $\left(\mathrm{C}_{6} \mathrm{H}_{14} \mathrm{O}_{6}\right.$, Sigma-Aldrich, $\geq 99 \%$ purity $)$, in boiled and degassed milliQ water. In the potentiometric titration experiments, potassium nitrate $\left(\mathrm{KNO}_{3}\right.$, Sigma-Aldrich, $\geq 99 \%$ purity) was used as a background electrolyte $(0.1 \mathrm{M})$ and $\mathrm{KOH}$ ( $>85 \%$, Sigma-Aldrich) to increase the $\mathrm{pH}$ values to $11.3,12.3,12.7$ and 13.0 . For the solubility measurement, portlandite, calcium hydroxide $\left(\mathrm{Ca}(\mathrm{OH})_{2}\right.$, Sigma-Aldrich, $\left.\geq 95 \%\right)$ was used.

It is important to note that the hexitols used in this study are all isomers, sharing the formula, $\mathrm{HOCH}_{2}(\mathrm{CHOH})_{4} \mathrm{CH}_{2} \mathrm{OH}$, but differ in the stereochemical arrangement of the $\mathrm{OH}$ groups as illustrated in Figure 1.

\subsection{Solubility experiments}

For the solubility experiments, various series of samples were prepared in a glove box with $3.92 \mathrm{~g}$ of $\mathrm{Ca}(\mathrm{OH})_{2}$, as a solid buffer, enclosed in a dialysis membrane and then placed in a $250 \mathrm{~mL}$ polypropylene flask filled with $200 \mathrm{~mL}$ of $\mathrm{CO}_{2}$-free solution with different amounts and type of organic molecule, see Figure 2. Prior to use, the dialysis membranes (Spectra / Por, MWCO 12-14 $\mathrm{kD}$ ) were dipped in distilled water for 30 minutes to remove any organic residues and dried in a desiccator overnight; the dialysis bags were closed with polyamide clamps (Carl Roth, length 50 $\mathrm{mm})$. Finally, the samples were stored in a $16 \mathrm{~L}$ plastic barrel filled with $\mathrm{N}_{2}$ gas, to guarantee $\mathrm{CO}_{2}$ free conditions, and placed on a shaking table during four weeks at $23^{\circ} \mathrm{C}$ to ensure a proper equilibrium. 
127 The $\mathrm{pH}$ values were recorded after removing the dialysis bags from the bottles. The $\mathrm{pH}$ electrode

128 (Consort C931 electrochemical analyser) was calibrated using Sigma Aldrich buffer ( $\mathrm{pH}$ 4, 7, 9 and

129 12). The total concentration of the elements $\mathrm{Ca}$ and $\mathrm{Si}$ was measured by inductively coupled

130 plasma-optic emission spectroscopy (ICP-OES 5110, Agilent).

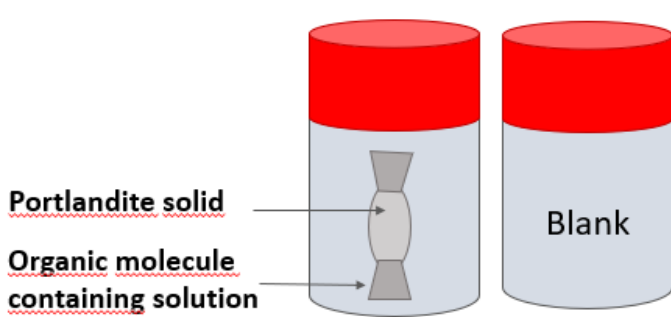

132

133

134 detection threshold for this device is very low $(4 \mu \mathrm{g} / \mathrm{L})$. each sample pair.

Figure 2: Schematic representation of a pair of samples used for the solubility and adsorption experiments. The flask used for the solubility measurement contains a dialysis bag filled with portlandite powder, immersed in a solution containing the organic molecule. The second flask contains the organic molecule solution only and is used as a blank/reference to verify the organic concentration introduced initially. This allows the determination of the organic adsorption on $\mathrm{C}-\mathrm{S}-\mathrm{H}$ by mass balance based on the measured difference. Note that the same stock solution is used for

The bulk concentration of organics at equilibrium was measured as total organic content with a TOC VCPN instrument (Shimadzu). This method is based on the oxidation of organic molecules contained in solution by gaseous oxygen with a platinum-based catalyst in an oven raised to a temperature of $720^{\circ} \mathrm{C}$. The $\mathrm{CO}_{2}$ formed is detected by Infra-Red Non-Dispersive (NDIR). The 


\subsection{Titration of $\mathrm{Ca}^{2+}$ with the ion selective electrode}

149 The chemical activity of calcium ions was also determined from potentiometric titration measurements using an automatic titrator instrument (Metrohm 905 Titrando); the setup is detailed in Figure 3. All measurements were performed in a titration reactor thermostated to $23.0 \pm 0.1^{\circ} \mathrm{C}$. The titrated solutions were continuously stirred at a constant rate $430 \mathrm{rpm}$. A nitrogen flow circulated continuously above the solution to avoid the ingress of $\mathrm{CO}_{2}$. It was taken care that the gas did not enter the solution to avoid any disturbance of the electrodes. In the reactor, $100 \mathrm{~mL}$ of a solution containing $0.1 \mathrm{M} \mathrm{KNO}_{3}$ background electrolyte and $0.25 \mathrm{mM} \mathrm{Ca}\left(\mathrm{NO}_{3}\right)_{2}$ was thermostated for approximately 20 minutes before the start of the titration. After 3 minutes of equilibration time, and only if the change in the electrode signal was $<0.5 \mathrm{mV} / \mathrm{min}$, a titrant solution containing $0.2 \mathrm{M}$ of organic molecule was added drop by drop $(0.2 \mathrm{ml}, 50$ times for a total volume added of $10 \mathrm{ml})$ at the maximal speed registered in the software "Tiamo" (Metrohm). The $\mathrm{Ca}^{2+}$ activity was measured at $23.0 \pm 0.1^{\circ} \mathrm{C}$ with a calcium sensitive electrode (Metrohm Ca ISE, 6.0508.110) coupled to a reference electrode (Metrohm Ag, $\mathrm{AgCl} / 3 \mathrm{M} \mathrm{KCl}, 6.0750 .100$ ). A stable electrode signal could only be obtained with the use of a background electrolyte. The titrations were thus performed in $0.1 \mathrm{M} \mathrm{KNO}_{3}$ to ensure a stable signal and to limit the influence of the background electrolyte on the complex formation. We have chosen potassium nitrate as $\mathrm{K}^{+}$ interferes less with the $\mathrm{Ca}^{2+}$ - selective electrode than $\mathrm{Na}^{+}(31)$. The $\mathrm{Ca}^{2+}$ electrode was calibrated prior to the measurements by a titration of $100 \mathrm{mM} \mathrm{KNO}_{3}$ solution with a solution containing 500 $\mathrm{mM} \mathrm{Ca}\left(\mathrm{NO}_{3}\right)_{2}(0.2 \mathrm{ml}, 50$ times for a total volume added of $10 \mathrm{ml})$ and by plotting the measured $\mathrm{mV}$ against the calculated $\mathrm{Ca}^{2+}$ activity calculated with PHREEQC as detailed below. The response 169 of the $\mathrm{Ca}^{2+}$ electrode was found to be linear with a slope of $29 \pm 1 \mathrm{mV}$, which corresponds to the expected slope of $29.4 \mathrm{mV}$ at $23^{\circ} \mathrm{C}$. The $\mathrm{pH}$ was determined with a pH electrode (Metrohm $\mathrm{pH}$ Unitrode with Pt 1000, 6.0259.100), which allows reliable measurements up to $\mathrm{pH}=14$. The $\mathrm{pH}$ 
172 electrode was calibrated prior to the measurements with standard buffer solutions $(\mathrm{pH} \mathrm{9,10,} \mathrm{and}$

17312.45 from Sigma Aldrich).

174

175

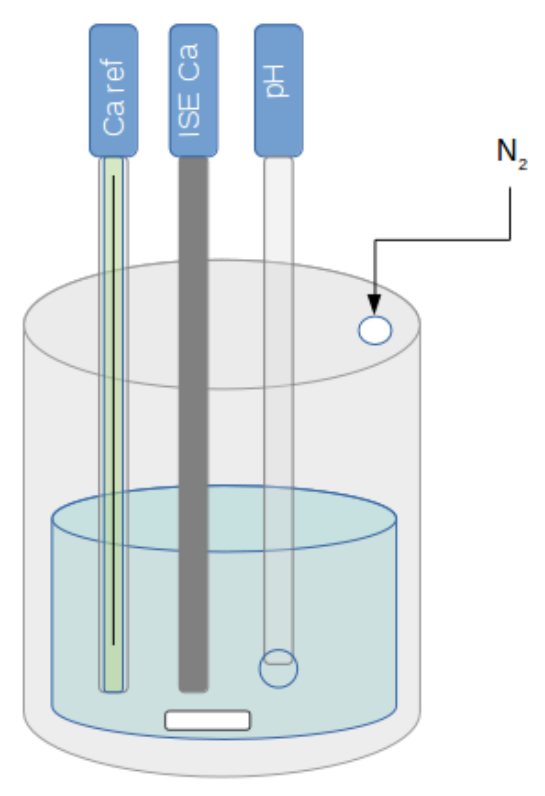

176 Figure 3: Schematic representation of the experimental titration set up: the reactor contains the

177 titrated solution, the calcium specific electrode, the reference electrode, and the $\mathrm{pH}$ electrode.

180 The solubility of portlandite and the activity of $\mathrm{Ca}^{2+}$ were fitted with a speciation model solved by

181 the geochemical software PHREEQC version 3 (3.6.2-15100) (32) and the WATEQ4f database

182 (33). The activity of the $\mathrm{Ca}^{2+}, a_{\mathrm{Ca} 2+}$, and all other species was calculated according to $a_{\mathrm{Ca} 2+}=$

$183 \gamma_{\mathrm{Ca} 2+} \cdot \mathrm{m}_{\mathrm{Ca} 2+}$, where $\gamma_{\mathrm{Ca} 2+}$ is the activity coefficient and $\mathrm{m}_{\mathrm{Ca} 2+}$ the molality in $\mathrm{mol} / \mathrm{kg} \mathrm{H}_{2} \mathrm{O}$. The

184 activity coefficients were calculated with the WATEQ Debye Hückel equation:

$\log \gamma_{i}=\frac{-A_{y} z_{i}^{2} \sqrt{I}}{1+B_{y} a_{i} \sqrt{I}}+b_{y} I$

186 where $\mathrm{z}_{i}$ denotes the charge of species $i$, I is the effective molal ionic strength, while $a_{i}$, the ion-size

187 parameter, and $b_{y}$ are ion specific parameters and $\mathrm{A}_{y}$ and $\mathrm{B}_{y}$ are pressure- and temperature- 
188 dependent coefficients (33). This activity correction is applicable up to approximately $1 \mathrm{M}$ of ionic

189 strength (34).

190 Table 1. Complex formation constants K, expressed in $\log \mathrm{K}$, between calcium and gluconate

$191\left(\mathrm{Gluc}^{-}\right)$at standard conditions $\left(1 \mathrm{bar}, 25^{\circ} \mathrm{C}\right)$ reported in literature and determined in the present

192 study.

\begin{tabular}{|c|c|c|c|c|c|c|c|}
\hline & $\begin{array}{c}\text { Sayer }(28) \\
0 \mathrm{M}\end{array}$ & $\begin{array}{c}\text { Masone }(27) \\
(0.5 M) 0 \mathrm{M}^{1}\end{array}$ & $\begin{array}{c}\text { Zhang (35) } \\
(0.1 M) 0 \mathrm{M}\end{array}$ & $\begin{array}{l}\text { Pallagi }(24) \\
(1 M) 0 \mathrm{M}\end{array}$ & $\begin{array}{c}\text { Bretti }(36) \\
\text { OM }\end{array}$ & $\begin{array}{l}\text { Kutus (26) } \\
(1 M) 0 \mathrm{M}\end{array}$ & $\begin{array}{c}\text { This study } \\
0 \mathrm{M}\end{array}$ \\
\hline \multicolumn{8}{|l|}{$\underline{\text { Solid }}$} \\
\hline $\mathrm{Ca}^{2+}+2 \mathrm{OH}^{-}=\mathrm{Ca}(\mathrm{OH})_{2}$ & - & - & - & - & - & - & $-5.20^{a}$ \\
\hline \multicolumn{8}{|l|}{ Aqueous complexes } \\
\hline $\mathrm{Ca}^{2+}+\mathrm{OH}^{-}=\mathrm{CaOH}^{+}$ & - & - & - & (0.97) 1.83 & - & - & $1.22^{\mathrm{a}}$ \\
\hline GlucH $^{0}=$ Gluc $^{-}+\mathrm{H}^{+}$ & 3.7 & - & $(3.30) 3.53$ & $(3.24) 3.64^{b}$ & 3.71 & - & 3.64 \\
\hline $\begin{array}{l}\mathrm{Gluc}^{-}+\mathrm{OH}^{-} \\
=\mathrm{GlucOH}^{2-\mathrm{c}}\end{array}$ & - & - & - & $(0.08)-0.44$ & - & - & -0.44 \\
\hline $\begin{array}{l}\mathrm{Ca}^{2+}+\mathrm{Gluc}^{-} \\
=\mathrm{CaGluc}^{+}\end{array}$ & 1.21 & (1.05) 1.79 & - & $(0.37) 1.23$ & - & $(0.70) 1.56$ & 1.56 \\
\hline $\begin{array}{l}\mathrm{Ca}^{2+}+2 \mathrm{Gluc}^{-} \\
=\mathrm{CaGluc}_{2}{ }^{0}\end{array}$ & - & (1.88) 2.98 & - & - & - & $\left(1.65^{d}\right) 2.9$ & 2.85 \\
\hline $\begin{array}{l}\mathrm{Ca}^{2+}+\mathrm{OH}^{-}+\mathrm{Gluc}^{-} \\
=\mathrm{CaGlucOH}^{0}\end{array}$ & - & - & - & $(2.82) 4.07$ & - & $\left(2.86^{d}\right) 4.11$ & $3.95^{\mathrm{e}}$ \\
\hline $\begin{array}{l}2 \mathrm{Ca}^{2+}+3 \mathrm{OH}^{-}+\mathrm{Gluc}^{-} \\
=\mathrm{Ca}_{2} \mathrm{Gluc}(\mathrm{OH})_{3}{ }^{0}\end{array}$ & - & - & - & (8.04) 10.48 & & - & - \\
\hline $\begin{array}{l}2 \mathrm{Ca}^{2+}+4 \mathrm{OH}^{-}+2 \mathrm{Gluc}^{-} \\
=\mathrm{Ca}_{2} \mathrm{Gluc}_{2}(\mathrm{OH})_{4}^{2-}\end{array}$ & - & - & - & - & - & $\left(9.49^{d}\right) 11.34$ & $11.25^{\mathrm{e}}$ \\
\hline $\begin{array}{l}3 \mathrm{Ca}^{2+}+4 \mathrm{OH}^{-}+2 \mathrm{Gluc}^{-} \\
=\mathrm{Ca}_{3} \mathrm{Gluc}_{2}(\mathrm{OH})_{4}{ }^{0}\end{array}$ & - & - & & (12.44) 16.07 & - & $\begin{array}{c}\left(12.59^{d}\right) \\
16.22\end{array}$ & $16.10^{\mathrm{e}}$ \\
\hline
\end{tabular}

193 Values reported for $\mathrm{I}=0.1,0.5$ and $1 \mathrm{M}$ extrapolated to $0 \mathrm{M}$ ionic strength in this study using the WATEQ Debye

194 Huckel equation (1); - : not reported; ${ }^{a}$ values from Thoenen et al. (37); ${ }^{\mathrm{b}}$ value from Pallagi et al. $(23) ;{ }^{\mathrm{c}}$ notation

$195 \mathrm{GlucOH}^{2-}$ represents the two times deprotonated $\mathrm{C}_{6} \mathrm{O}_{7} \mathrm{H}_{10}{ }^{-2}$ as suggested in $(24) ;{ }^{\mathrm{d}}$ recalculated from reaction

196 formulated with $\mathrm{H}+(26)$ using a $\log \mathrm{K}_{\mathrm{w}}$ of -13.62 at $1 \mathrm{M} \mathrm{NaCl} ;{ }^{\mathrm{e}}$ fitted in this study 
Table 2. Complex formation constants, expressed in log K, between calcium and sorbitol (Sorb), mannitol (Man) and galactitol (Gal) at standard conditions $\left(1 \mathrm{bar}, 25^{\circ} \mathrm{C}\right)$ reported in literature and

204 determined in the present study.

\begin{tabular}{|c|c|c|c|c|}
\hline & $\begin{array}{l}\text { Kieboom }(30) \\
(0.2-0.8 M) 0 \mathrm{M}\end{array}$ & $\begin{array}{l}\text { Haas }(29) \\
(0.7 M) 0 \mathrm{M}\end{array}$ & $\begin{array}{l}\text { Kutus (25) } \\
(1 M) 0 \mathrm{M}\end{array}$ & $\begin{array}{l}\text { This study } \\
\text { OM }\end{array}$ \\
\hline $\mathrm{Ca}^{2+}+$ Sorb $^{0}=$ CaSorb $^{2+}$ & $(0.11) 0.08$ & $(-0.52)-0.54$ & (0) -0.06 & $0.10^{\mathrm{a}}$ \\
\hline \multicolumn{4}{|l|}{$\mathrm{Ca}^{2+}+\mathrm{Sorb}^{0}+\mathrm{OH}^{-}=\mathrm{SorbCaOH}^{+}$} & $2.85^{\mathrm{a}}$ \\
\hline \multicolumn{4}{|l|}{$\begin{array}{l}2 \mathrm{Ca}^{2+}+2 \mathrm{Sorb}^{0}+4 \mathrm{OH}^{-}= \\
\mathrm{Ca}_{2} \mathrm{Sorb}_{2}(\mathrm{OH})_{4}{ }^{0}\end{array}$} & $9.75^{a}$ \\
\hline $\mathrm{Ca}^{2+}+\mathrm{Man}^{0}=\mathrm{CaMan}^{2+}$ & $(-0.05)-0.08$ & $(-0.62)-0.64$ & $(-0.3)-0.36$ & -0.36 \\
\hline \multicolumn{4}{|l|}{$\mathrm{Ca}^{2+}+\mathrm{Man}^{0}+\mathrm{OH}^{-}=\mathrm{CaManOH}^{+}$} & $2.65^{\mathrm{a}}$ \\
\hline \multicolumn{4}{|l|}{$\begin{array}{l}2 \mathrm{Ca}^{2+}+2 \mathrm{Man}^{0}+4 \mathrm{OH}^{-}= \\
\mathrm{Ca}_{2} \mathrm{Man}_{2}(\mathrm{OH})_{4}{ }^{0}\end{array}$} & $9.23^{a}$ \\
\hline \multicolumn{2}{|l|}{$\mathrm{Ca}^{2+}+\mathrm{Gal}^{0}=\mathrm{CaGal}^{2+}$} & $(-0.51)-0.53$ & & -0.53 \\
\hline \multicolumn{3}{|l|}{$\mathrm{Ca}^{2+}+\mathrm{Gal}^{0}+\mathrm{OH}^{-}=\mathrm{CaGalOH}^{+}$} & & $2.80^{\mathrm{a}}$ \\
\hline \multicolumn{4}{|c|}{$2 \mathrm{Ca}^{2+}+2 \mathrm{Gal}^{0}+4 \mathrm{OH}^{-}=\mathrm{Ca}_{2} \mathrm{Gal}_{2}(\mathrm{OH})_{4}{ }^{0}$} & $9.29^{\mathrm{a}}$ \\
\hline
\end{tabular}

${ }^{\mathrm{a}}$ Fitted in this study

The complex formation constants between $\mathrm{Ca}^{2+}$ and hydroxide, gluconate, sorbitol, mannitol and galactitol reported in the literature and determined in the present study are detailed in Table 1 and

Table 2. For gluconate, sorbitol and mannitol we used as starting values the complexes and associated constants derived from Pallagi and co-workers (23) (24) (25) (26). They were, where necessary, further refined to obtain a good visual fit between the measured and the modeled data.

212 The following procedure to refine the complexation constants was employed. First, the

213 potentiometric data measured at $\mathrm{pH} 11.3$ were used to fit the constants for the $\mathrm{CaGluc}^{+}, \mathrm{CaSorb}^{2+}$, $214 \mathrm{CaMan}^{2+}$, and $\mathrm{CaGal}^{2+}$ complexes, which dominate at low $\mathrm{pH}$ values. Then, the titration data at 215 higher $\mathrm{pH}$ values were used to fit the constants for the $\mathrm{CaGlucOH}^{0}, \mathrm{CaSorbOH}^{+}, \mathrm{CaManOH}^{+}$, and $216 \mathrm{CaGalOH}^{+}$complexes. The formation of $\mathrm{CaGluc}_{2}{ }^{2}$, suggested by Pallagi et al. (23) and Kutus et al. 217 (26), and of $\mathrm{Ca}_{2} \mathrm{Gluc}_{2} \mathrm{OH}_{4}{ }^{2-}$ and $\mathrm{Ca}_{3} \mathrm{Gluc}_{2} \mathrm{OH}_{4}{ }^{0}$ complexes suggested by Kutus et al. (26), were also 218 considered. Only traces of the $\mathrm{CaGluc}_{2}{ }^{0}$ complex were calculated to be present in our experiments 219 (less than $1 \%$ of the total $\mathrm{Ca}$ in any of the experiments) thus this complex was considered but its 
constant not further refined. The presence of $\mathrm{Ca}_{3} \mathrm{Gluc}_{2} \mathrm{OH}_{4}{ }^{0}$ and $\mathrm{Ca}_{2} \mathrm{Gluc}_{2} \mathrm{OH}_{4}{ }^{2-}$ complex is not important at low calcium concentrations (i.e. the conditions used in this study for the potentiometric titration) but in the presence of portlandite. Thus their constants were refined using the solubility data of portlandite.

The $\mathrm{CaSorb}^{2+}, \mathrm{CaMan}^{2+}$, and $\mathrm{CaGal}^{2+}$ complexes reported in the literature were not found to be in significant quantities in any of our experiments, as they were obtained in near neutral $\mathrm{pH}$ conditions. Furthermore, the reported values of the complex formation constants are rather scattered, maybe due to the different methods employed to determine them. We thus introduced in addition $\mathrm{CaHexitolOH}^{+}$complexes, which were found to give a very satisfactory description of our experimental data. As it will be described in the next section, the complexation of calcium by the hexitols is much weaker than by gluconate.

The so-obtained complexation constant are compiled together with the literature values in Table 1 and 2.

\section{Results and discussion}

\subsection{Gluconate}

\subsubsection{Solubility experiment with portlandite}

The calcium concentrations in equilibrium with portlandite rise rapidly (Figure 4), when the gluconate concentration is increased. In the absence of gluconate, a calcium concentration of 21 $\mathrm{mM}$ was observed, which corresponds well with the expected solubility of portlandite of $21 \mathrm{mM}$ at $23^{\circ} \mathrm{C}$. The presence of gluconate increased the total measured calcium concentrations up to $101 \mathrm{mM}$ $\mathrm{Ca}$ at a gluconate concentration of $68 \mathrm{mM}$, due to the formation of different Ca-gluconate complexes as shown in Figure 4. This strong increase of portlandite solubility in the presence of gluconate agrees well with observations reported by Nalet and Nonat (19). The measured increase 
245 of the total calcium concentrations $\left([\mathrm{Ca}]_{\text {total }}=\left[\mathrm{Ca}^{2+}\right]+\left[\mathrm{CaOH}^{+}\right]+[\mathrm{Ca}\right.$-organic $\left.]\right)$ is mainly due to the 246 formation of $\mathrm{Ca}_{3} \mathrm{Gluc}_{2}(\mathrm{OH})_{4}{ }^{0}, \mathrm{CaGlucOH}^{0}$ and $\mathrm{Ca}_{2} \mathrm{Gluc}_{2}(\mathrm{OH})_{4}{ }^{2-}$ in presence of gluconate, while our 247 calculations indicate that the concentrations of $\mathrm{CaGluc}^{+}$, and $\mathrm{CaGluc}_{2}{ }^{0}$ are negligible. The over248 proportional increase of calcium $(80 \mathrm{mM}$ more calcium in solution in the presence of $68 \mathrm{mM}$ 249 gluconate) is consistent with the presence of the heteropolynuclear complex $\mathrm{Ca}_{3} \mathrm{Gluc}_{2}(\mathrm{OH})_{4}{ }^{0}$, which 250 contains more calcium than gluconate. At gluconate concentrations of above $20 \mathrm{mM}$ the

$251 \mathrm{Ca}_{3} \mathrm{Gluc}_{2}(\mathrm{OH})_{4}{ }^{0}$ complex dominates $\mathrm{Ca}$-speciation in the presence of portlandite as shown in Figure

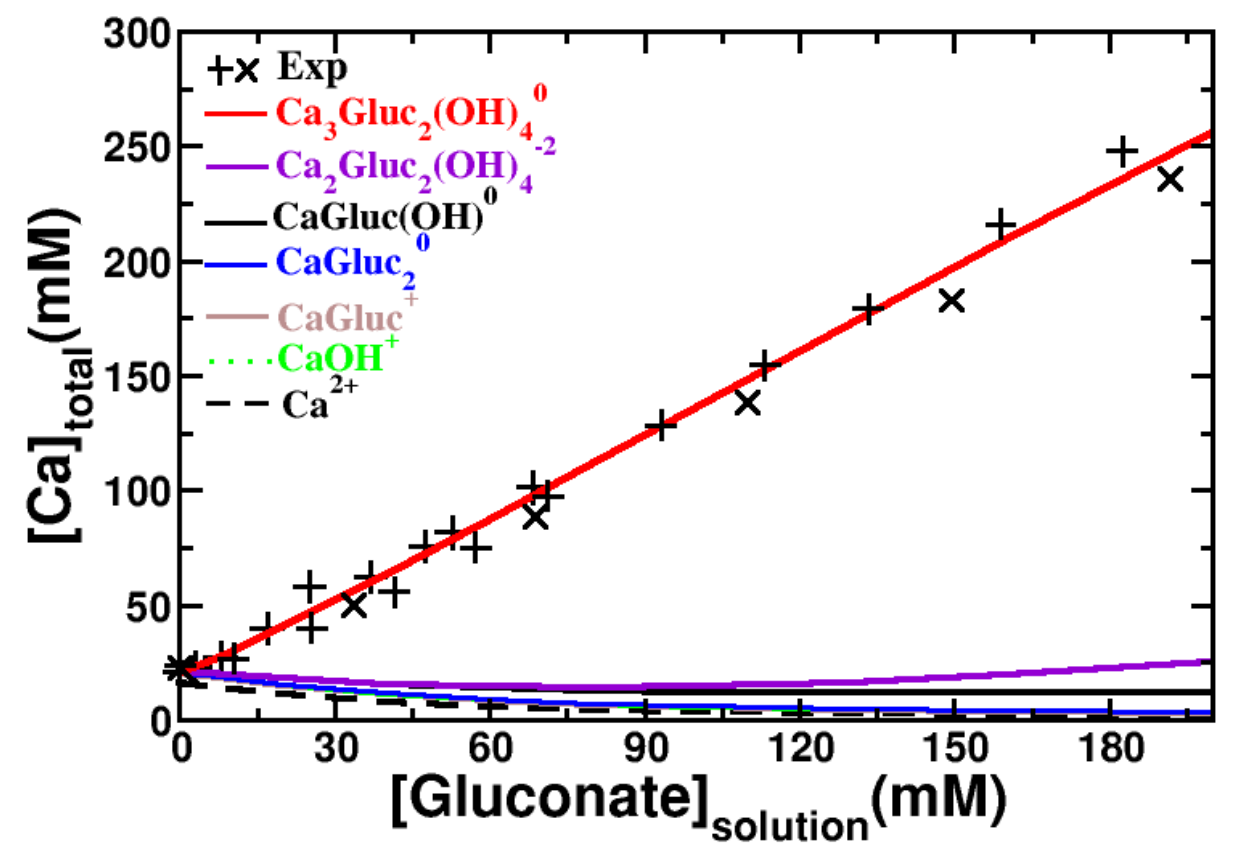

Figure 4: Evolution of total calcium concentrations in equilibrium with portlandite (initial $\mathrm{pH}$ 12.6, final $\mathrm{pH}$ 12.8) as a function of the gluconate concentration. The crosses represent the total concentrations determined experimentally, while the solid lines represent the cumulative calcium complexes concentrations calculated using the data compiled in Table 1.

\subsubsection{Ca-gluconate titration}

259 The measured changes of the $\mathrm{Ca}^{2+}$ activity at various alkaline $\mathrm{pH}$ values upon the addition of 260 potassium gluconate to a solution containing $0.25 \mathrm{mM}$ calcium nitrate is shown in Figure 5. The 261 drop of the measured $\mathrm{Ca}^{2+}$ activity can be attributed i) to a minor extent to the dilution of the 262 solution by the addition of the titrant solution (for the effect of adding solution without organics see 
SI) and ii) to the complexation of $\mathrm{Ca}^{2+}$ with the added gluconate. As it can be seen in Fig. 5 a very

264 good fit of the experimental data with our speciation model is obtained at all $\mathrm{pH}$ values.
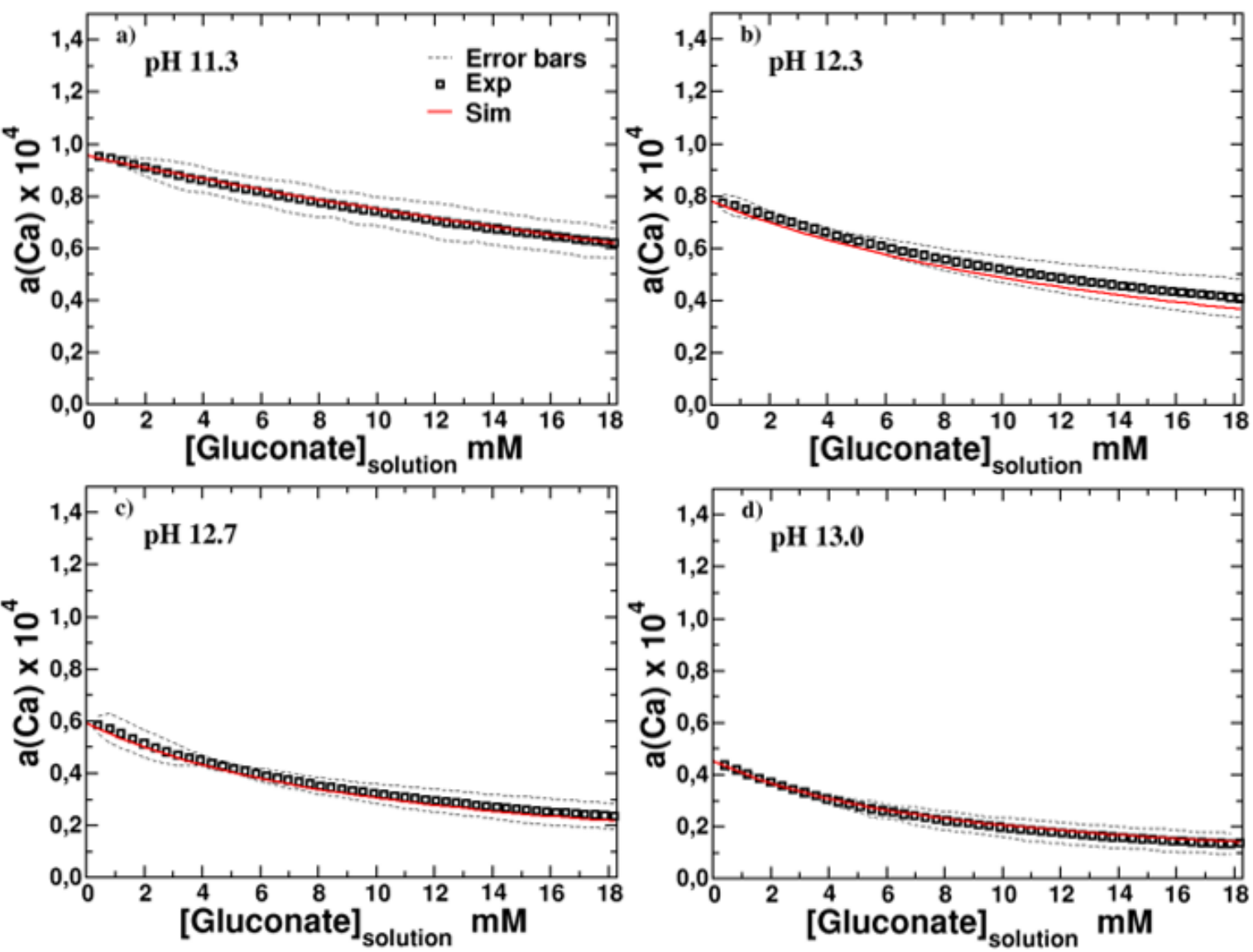

Figure 5: $\mathrm{Ca}^{2+}$ activities, $a_{\mathrm{Ca}}$, in a solution containing $0.25 \mathrm{mM} \mathrm{Ca}\left(\mathrm{NO}_{3}\right)_{2}$ and increasing amounts of $200 \mathrm{mM}$ K-gluconate solution at $\mathrm{pH}$ a) 11.3 , b) 12.3 , c)12.7 and d) 13.0. The dots indicate the mean of three repetitions of the measurements and the dotted lines the observed standard deviations. The solid red lines show the modeled $a_{\mathrm{Ca}}$ based on the data compiled in Table 1 .

It can also be observed that the decrease in calcium activity is limited at $\mathrm{pH} 11.3$ but more distinct at higher $\mathrm{pH}$ values, which points towards the importance of calcium-gluconate-hydroxide complexes, as further confirmed below. 
In Figure 6 the simulated change in the calcium speciation in the same conditions as in Figure 5 is

278 given. In contrast in the solubility experiments, where high calcium concentrations (21 up to 100

$279 \mathrm{mM} \mathrm{Ca}$, see Figure 4) are present and the calcium complexation is dominated by the

280 heteropolynuclear $\mathrm{Ca}_{3} \mathrm{Gluc}_{2} \mathrm{OH}_{4}{ }^{0}$ complex, $\mathrm{CaGluc}^{+}$and $\mathrm{CaGlucOH}^{0}$ are the dominant complexes at

281 the low $\mathrm{Ca}$ concentrations used in the titration experiments. For the titration at $\mathrm{pH} 11.3$ mainly the

282 formation of some $\mathrm{CaGluc}^{+}$is predicted, while at $\mathrm{pH} 13.0$ the formation of $\mathrm{CaGlucOH}^{0}$ is

283 principally found, illustrating the strong influence of $\mathrm{pH}$ on the calcium speciation. In addition, it

284 can be noted that calcium shows a strong preference for the heterogeneous complex $\mathrm{CaGlucOH}^{0}$,

285 whose concentration is 5 times higher in the presence of $18.8 \mathrm{mM}$ gluconate than that of $\mathrm{CaOH}^{+}$at

$286 \mathrm{pH} 13\left(\sim 100 \mathrm{mM} \mathrm{OH}^{-}\right)$. Very low concentrations of the heteropolynuclear complexes,

$287 \mathrm{Ca}_{2} \mathrm{Gluc}_{2}(\mathrm{OH})_{4}{ }^{2-}$ and $\mathrm{Ca}_{3} \mathrm{Gluc}_{2}(\mathrm{OH})_{4}{ }^{0}$, were observed due to the relative low $\mathrm{Ca}(0.25 \mathrm{mM})$ and

288 gluconate $(18.8 \mathrm{mM})$ concentrations, at high $\mathrm{pH}(12.7$ and 13.0$)$.
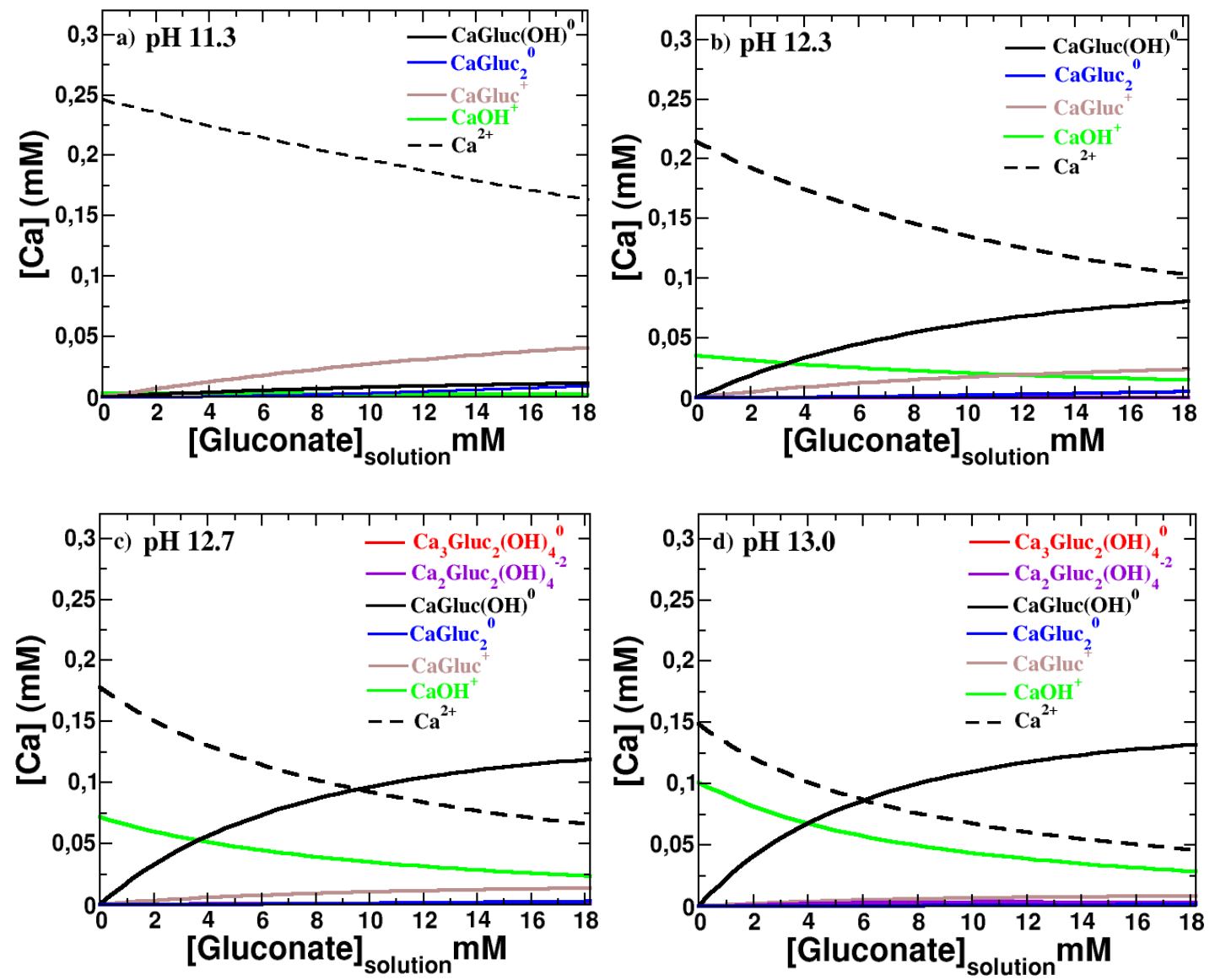
Figure 6: Calculated calcium concentrations (in $\mathrm{mM}$ ) in a solution of $0.25 \mathrm{mM} \mathrm{Ca}\left(\mathrm{NO}_{3}\right)_{2}$ during the titration with $200 \mathrm{mM}$ K-gluconate at $\mathrm{pH}$ a) 11.3, b) 12.3, c)12.7 and d) 13.0. The calculations are based on the thermodynamic data compiled in Table 1.

\subsection{Sorbitol}

\subsubsection{Solubility experiments with portlandite}

299 The equilibrium calcium concentration as obtained in the solubility experiments of portlandite in 300 the presence of sorbitol is given in Figure 7. The equilibrium calcium concentration is observed to increase moderately with that of sorbitol, from $21 \mathrm{mM}$ to $55 \mathrm{mM}$ when sorbitol is increased up to $211 \mathrm{mM}$. The increase is much weaker than the one due to gluconate (Figure 4), indicating a weaker complex formation between $\mathrm{Ca}^{2+}$ and sorbitol. The calculations show that the observed increase can be mainly explained by the formation of a $\mathrm{CaSorbOH}^{+}$complex, while the concentration of

$305 \mathrm{CaSorb}^{2+}$ is found to be negligible. No clear indication for the formation of polynuclear complexes 306 is found, although the underestimation of the total calcium concentration at very high sorbitol 307 concentrations could point towards the formation of such complex. At sorbitol concentrations of $308100 \mathrm{mM}$ and above, the $\mathrm{CaSorbOH}^{+}$complex dominates Ca-speciation (Figure 7).

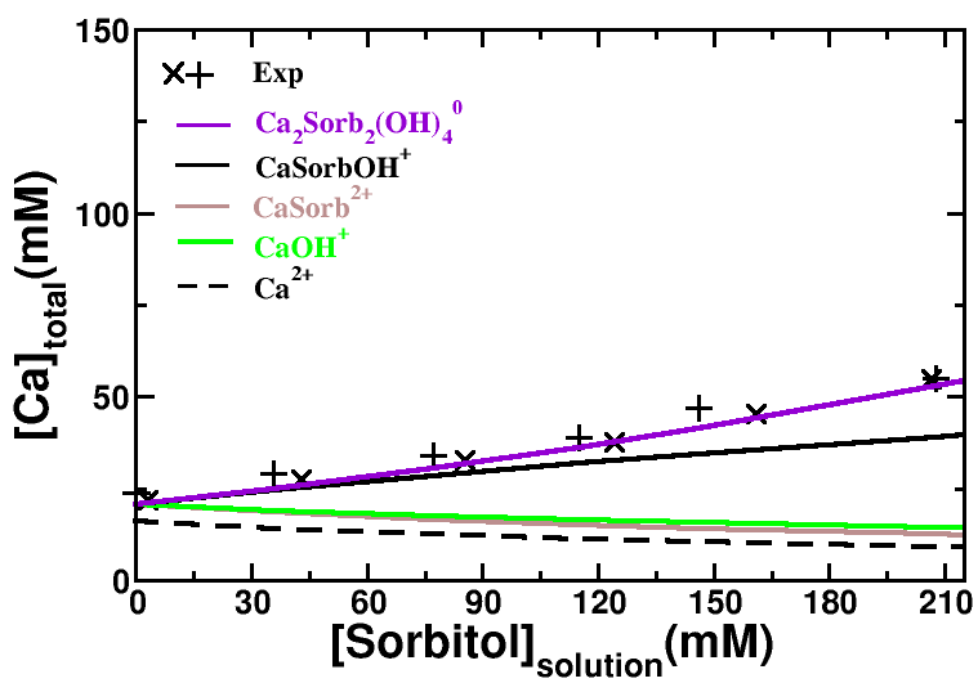

310 Figure 7: Evolution of the total calcium concentration in equilibrium with portlandite as a function

311 of the sorbitol concentration. The crosses represent the total calcium concentrations determined

312 experimentally, while the lines represent the calcium concentrations calculated using the data 
313 compiled in Table 2. The cumulative calcium concentrations due to $\mathrm{Ca}^{2+}$ (black, dashed line),

$314 \mathrm{CaOH}^{+}$(green, solid line), $\mathrm{CaSorb}^{2+}$ (grey, solid line), $\mathrm{CaSorbOH}^{+}$(black, solid line) and

$315 \mathrm{Ca}_{2} \mathrm{Sorb}_{2}(\mathrm{OH})_{4}{ }^{0}$ (purple, solid line) are also plotted.

\subsubsection{Ca-sorbitol titration}

318 The change in the activity of $\mathrm{Ca}^{2+}$ at different $\mathrm{pH}$ values upon the addition of sorbitol as measured

319 by potentiometric titration of a diluted calcium nitrate solution $(0.25 \mathrm{mM})$ is shown in Figure 8 . In 320 agreement with the solubility experiments (Fig.7), the drop of the $\mathrm{Ca}^{2+}$ activity is weaker than the 321 one observed with gluconate and more distinct at high $\mathrm{pH}$ values as explained by the formation of $322 \mathrm{CaSorbOH}^{+}$complex. This is illustrated in Figure 9, which provides the detailed calculated 323 speciation of calcium. As expected, $\mathrm{CaSorbOH}^{+}$is prevalent at $\mathrm{pH} 13$ and hardly visible at $\mathrm{pH}$ 11.3. 324 In line with the solubility experiments, the $\mathrm{CaSorb}^{2+}$ complex is negligible in these alkaline 325 conditions. The overall good agreement obtained between modeled and experimentally observed 326 decrease of the $\mathrm{Ca}^{2+}$ activities clearly shows that no or only very little polynuclear Ca-sorbitol 327 complexes are present.
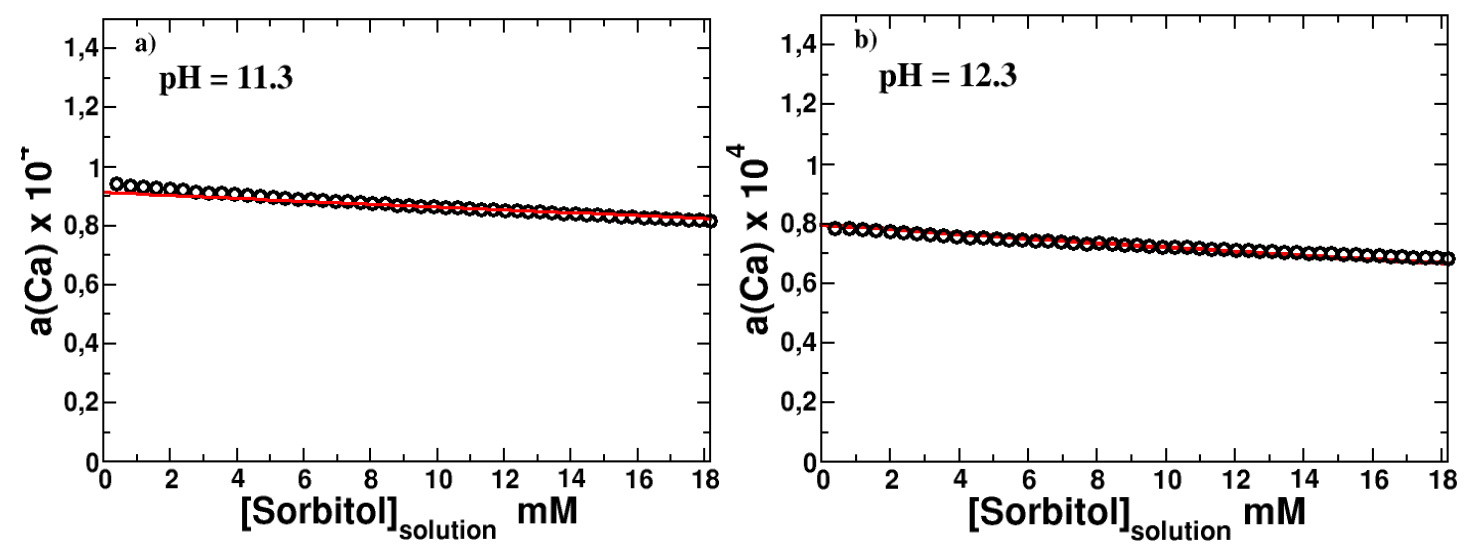

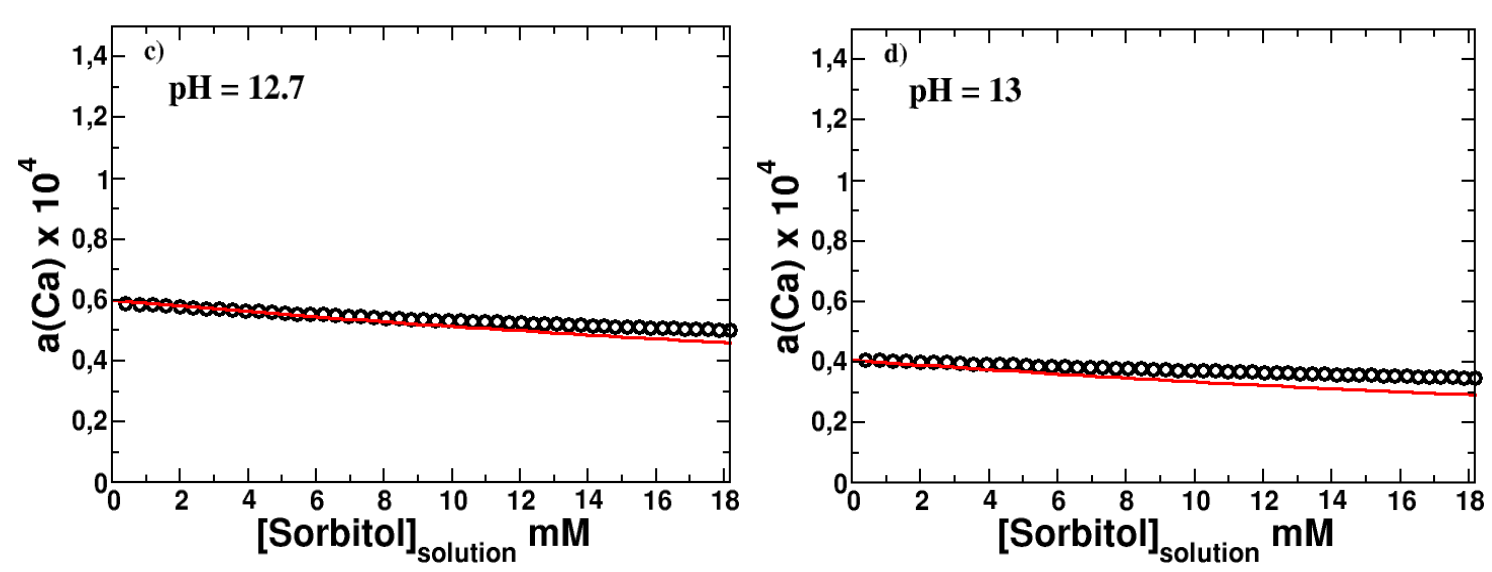

330 Figure 8: $\mathrm{Ca}^{2+}$ activities, $a_{\mathrm{Ca} 2+}$, in a solution containing $0.25 \mathrm{mM} \mathrm{Ca}\left(\mathrm{NO}_{3}\right)_{2}$ and increasing amounts 331 of $0.2 \mathrm{M}$ sorbitol solution at $\mathrm{pH}$ a) 11.3 , b) 12.3 , c) 12.7 and d) 13.0. The solid red lines show the 332 modeled $a_{\mathrm{Ca} 2+}$ based on the data compiled in Table 2.
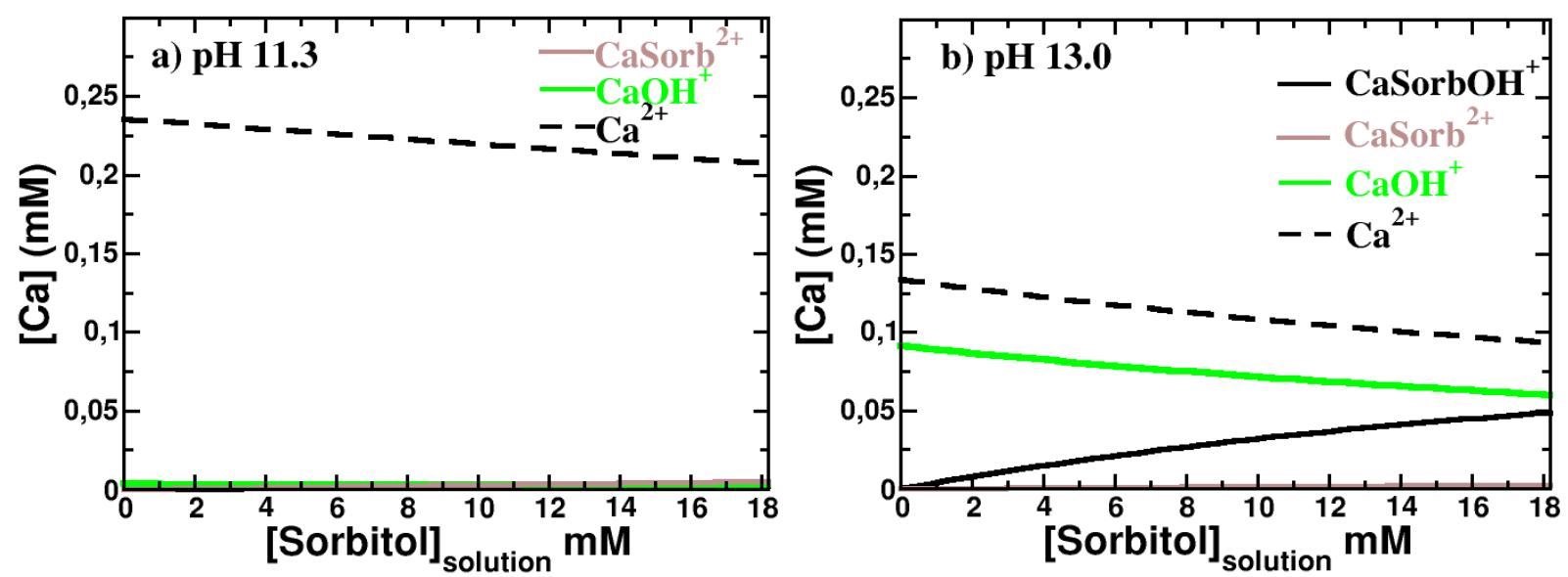

336 Figure 9: Calcium concentrations (in $\mathrm{mM}$ ) in a solution of $0.25 \mathrm{mM} \mathrm{Ca}\left(\mathrm{NO}_{3}\right)_{2}$ during the titration with sorbitol at a) $\mathrm{pH} 11.3$ and b) $\mathrm{pH} 13.0$ calculated based on the thermodynamic data compiled in Table 2.

\subsection{Mannitol and galactitol}

\subsubsection{Solubility experiments with portlandite}

343 The increase in the equilibrium calcium concentration in the solubility experiments of portlandite in

344 the presence of mannitol and galactitol, given in Figure 10, is comparable to that observed with 
sorbitol, although somewhat weaker compared with Figure 7. As for sorbitol, the observed increase

346 of the Ca concentration can be principally explained by the formation of $\mathrm{CaManOH}^{+}$and

$347 \mathrm{CaGalOH}^{+}$complexes, while the concentrations of $\mathrm{CaMan}^{2+}$ and $\mathrm{CaGal}^{2+}$ are negligible. Only at 348 mannitol and galactitol concentrations well above $100 \mathrm{mM}, \mathrm{CaManOH}^{+}$and $\mathrm{CaGalOH}^{+} \mathrm{complexes}$ 349 dominate the speciation of calcium (Figure 10).
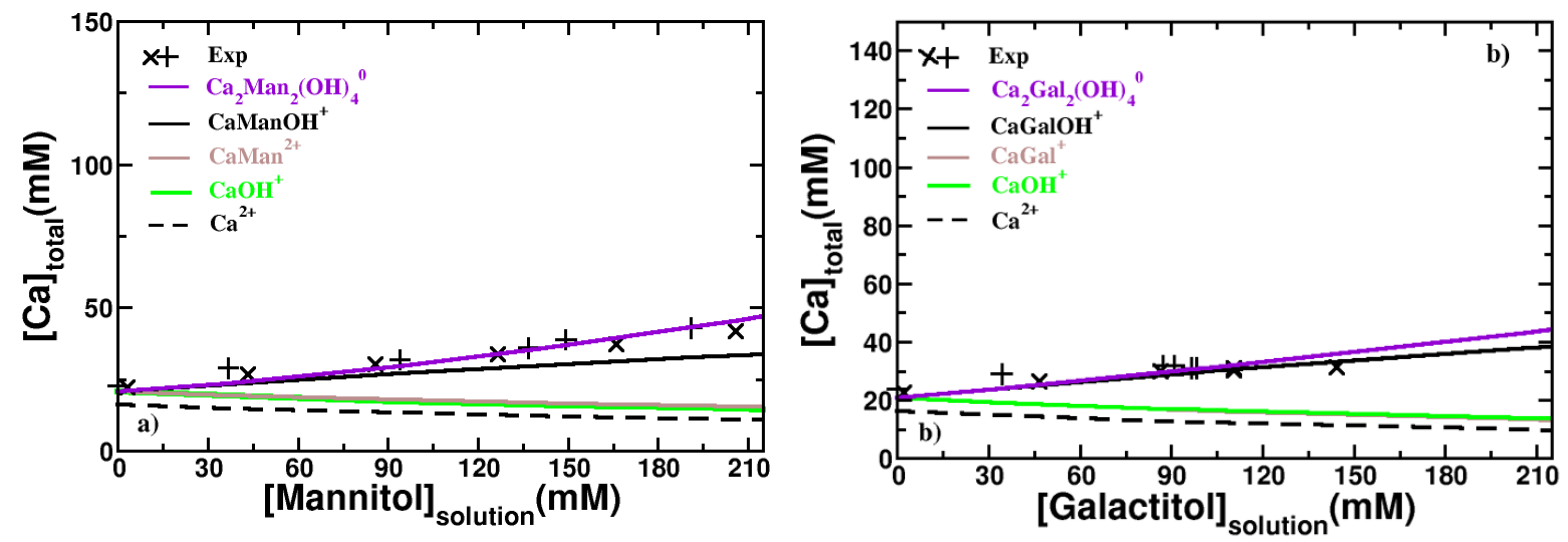

351 Figure 10: Evolution of calcium concentrations in equilibrium with portlandite at a $\mathrm{pH}$ value of 12.6 as a function of a) mannitol and b) galactitol concentration. The crosses represent the total calcium concentrations determined experimentally, while the lines represents the calcium concentrations calculated using the thermodynamic data compiled in Table 2 . The cumulative calcium concentrations of $\mathrm{Ca}^{2+}$ (black, dashed line ), $\mathrm{CaOH}^{+}$(green, solid line), $\mathrm{CaMan}^{2+}$ or $\mathrm{CaGal}^{2+}$ (grey, solid line), $\mathrm{Ca}_{2} \mathrm{Man}_{2}(\mathrm{OH})_{4}{ }^{0}$ or $\mathrm{Ca}_{2} \mathrm{Gal}_{2}(\mathrm{OH})_{4}{ }^{0}$ (purple, solid line) and $\mathrm{CaManOH}^{+}$or $\mathrm{CaGalOH}^{+}$ (black, solid line) are also plotted.

\subsubsection{Ca-mannitol and Ca-galactitol titration}

360 The change in the simulated and measured activity of $\mathrm{Ca}^{2+}$ and $\mathrm{pH}$ upon the addition of 0 to $18 \mathrm{mM}$ mannitol to a $0.25 \mathrm{mM}$ calcium nitrate at $\mathrm{pH} 11.3,12.3,12.7$ and 13.0 are shown in Figure 11 . The data for galactitol are similar and provided in the supplementary information. In agreement with the

363 solubility experiments of portlandite (Figure 10), the decrease in the measured aca2+ is less

364 pronounced than in the case of sorbitol and is mainly explained by the formation $\mathrm{CaManOH}^{+}$and $365 \mathrm{CaGalOH}^{+}$at higher $\mathrm{pH}$ values. 
366 The strong preference of calcium for the heterogeneous complex with hydroxide $\left(\mathrm{CaManOH}^{+}\right.$and $367 \mathrm{CaGalOH}^{+}$) is further illustrated in Figure 12.

368
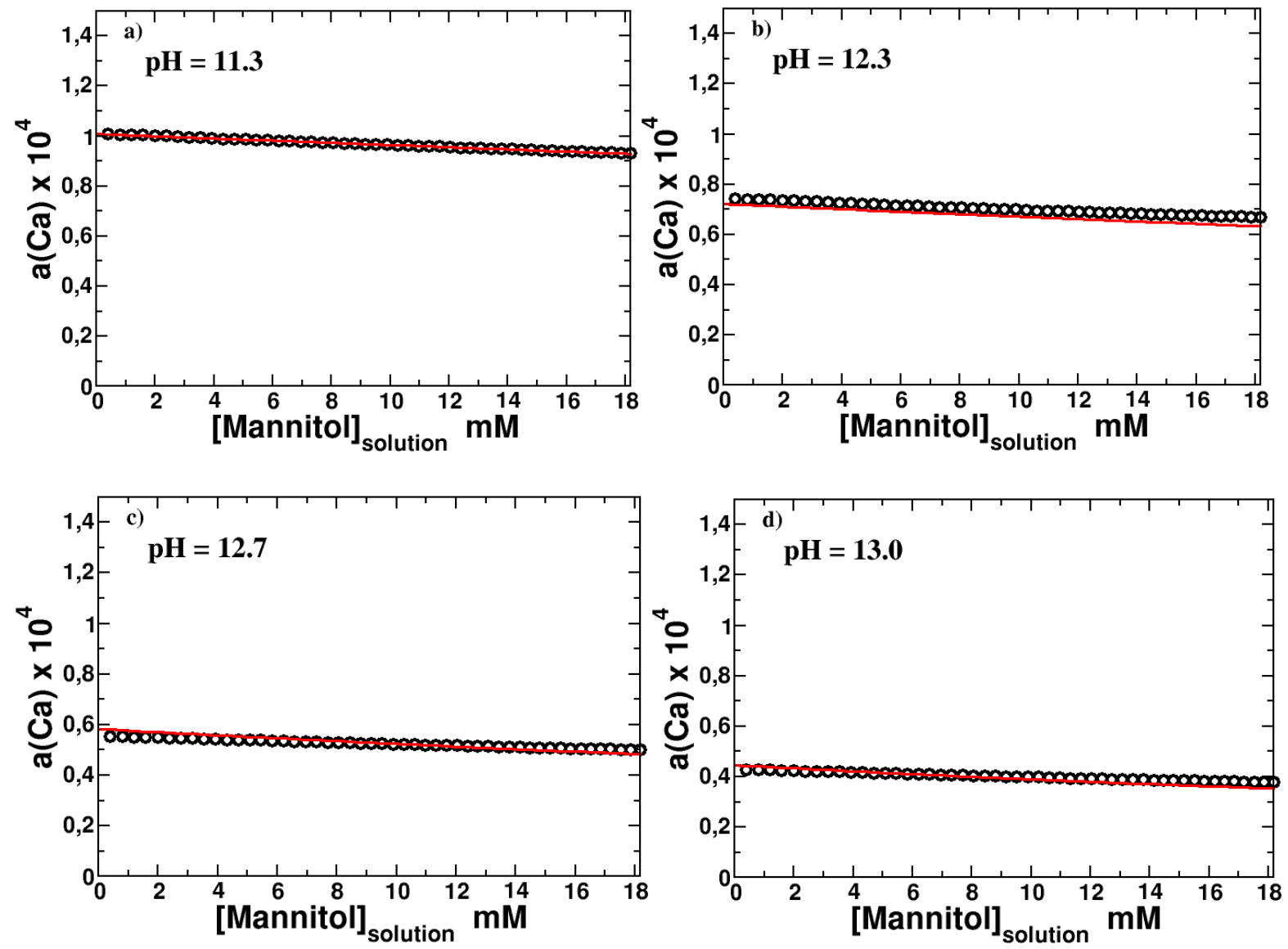

Figure 11: $\mathrm{Ca}^{2+}$ activities, $a_{\mathrm{Ca} 2+}$, in a solution containing $0.25 \mathrm{mM} \mathrm{Ca}\left(\mathrm{NO}_{3}\right)_{2}$ and increasing amounts of $0.2 \mathrm{M}$ mannitol solution at $\mathrm{pH}$ a) 11.3 , b) 12.3, c)12.7 and d) 13.0. The experimental points are shown by the empty circles. The solid red lines give the modeled $a_{\mathrm{Ca} 2+}$, based on the data compiled in Table 2, for comparison.
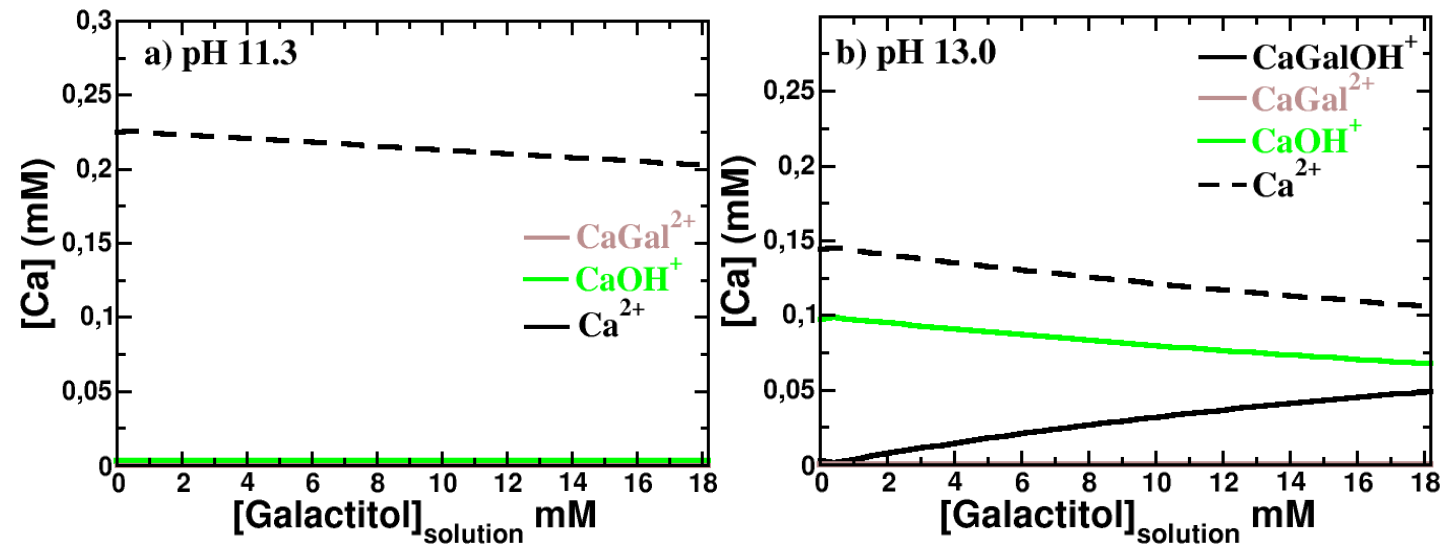

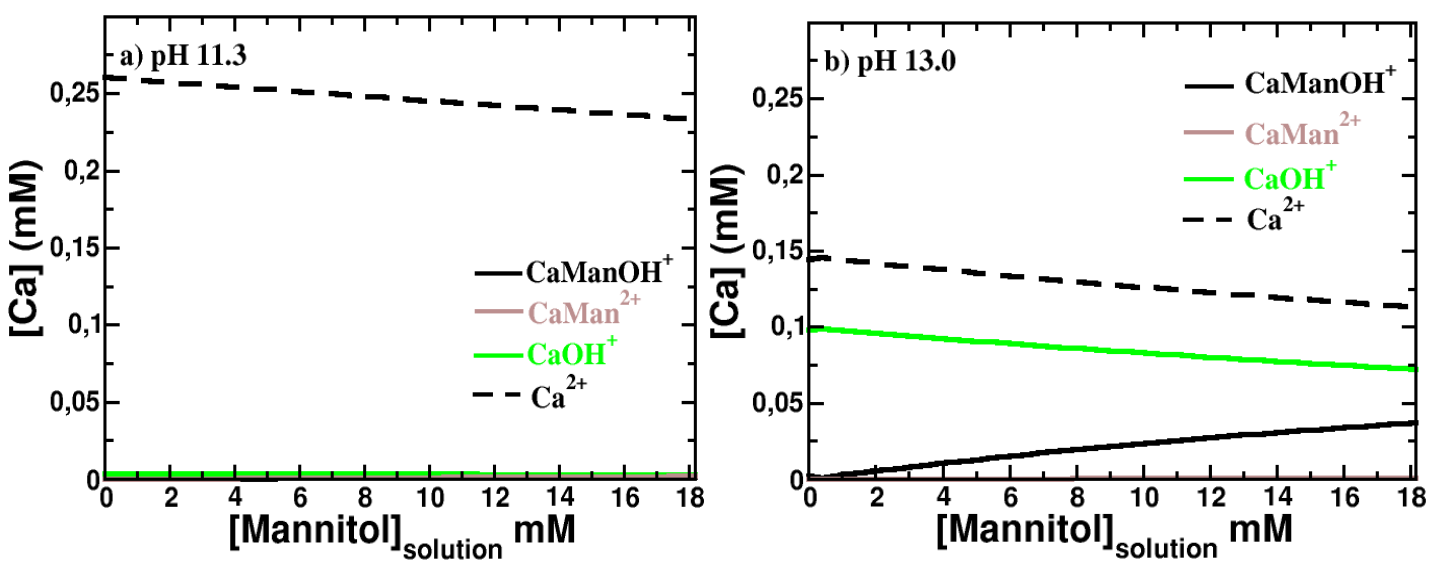

376

Figure 12: Simulated speciation of calcium in a solution of $0.25 \mathrm{mM} \mathrm{Ca}\left(\mathrm{NO}_{3}\right)_{2}$ during the titration with above a) galactitol at pH11.3 and b) galactitol at pH 13.0, and below, a) mannitol at pH 11.3 and b) mannitol at $\mathrm{pH}$ 13.0. The calculations are based on the thermodynamic data compiled in Table 2.

\subsection{Effect of complexation on calcium speciation}

Calcium has been observed to form a number of different complexes with gluconate and hydroxide.

Under conditions relevant for the early-age pore solution of cements (10-40 mM Ca, $\mathrm{pH} 12.5-13.5)$ mainly the $\mathrm{CaGlucOH}^{0}, \mathrm{Ca}_{3} \mathrm{Gluc}_{2}(\mathrm{OH})_{4}{ }^{0}$ and $\mathrm{Ca}_{2} \mathrm{Gluc}_{2}(\mathrm{OH})_{4}{ }^{-2}$ complexes are of importance as illustrated in Figure 13b. The importance of $\mathrm{CaGlucOH}^{0}, \mathrm{Ca}_{3} \mathrm{Gluc}_{2}(\mathrm{OH})_{4}{ }^{0}$ and $\mathrm{Ca}_{2} \mathrm{Gluc}_{2}(\mathrm{OH})_{4}{ }^{-2}$ complexes at $\mathrm{pH}$ values above 12.5 result in much lower concentrations of free $\mathrm{Ca}^{2+}$ than in the absence of gluconate. The effect can be expected to be even stronger at later hydration times, where calcium concentrations drop to a few $\mathrm{mM}$, while the concentrations of small organic molecules in the pore solutions tend to remain high. This leads to a stabilization of $\mathrm{CaGlucOH}^{0}$ as shown in Figure $13 \mathrm{a}$ and lower $\mathrm{Ca}^{2+}$ concentrations.

The strong complexation of calcium can be expected to retard portlandite and C-S-H precipitation during cement hydration. Gluconate sorbs also strongly on calcium at the surface of $\mathrm{C}_{3} \mathrm{~S}$, portlandite (see Supplementary Information) and C-S-H (18) (19), which will also strongly influence their dissolution and formation rate. 

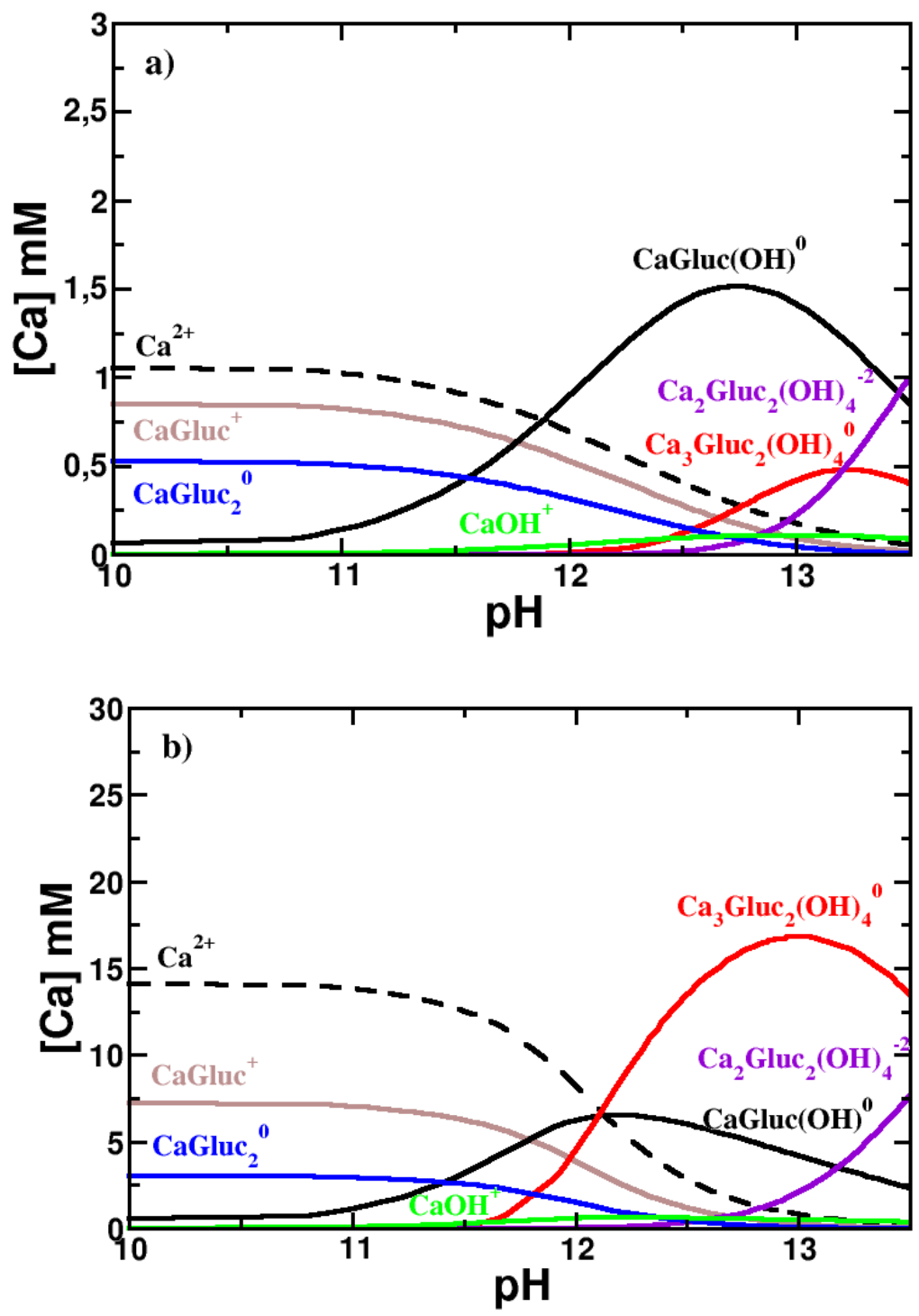

398 Figure 13: Calcium distribution (expressed as $\mathrm{mM} \mathrm{Ca}$ ) in a solution containing a) $2.5 \mathrm{mM}$ of $\mathrm{Ca}$, b)

$39925 \mathrm{mM}$ of $\mathrm{Ca}$ and $50 \mathrm{mM}$ of gluconate in the $\mathrm{pH}$ range 10 to 13.5 .

401 Calcium forms only relatively weak complexes with the three hexitols investigated, in the order

402 sorbitol > mannitol > galactitol. Thermodynamic modelling indicates a non negligeable Ca-

403 complexation in conditions relevant for the pore solution of cements (10-40 mM Ca, $\mathrm{pH} 12.5-13.5)$

404 as illustrated for sorbitol in Figure 14. 

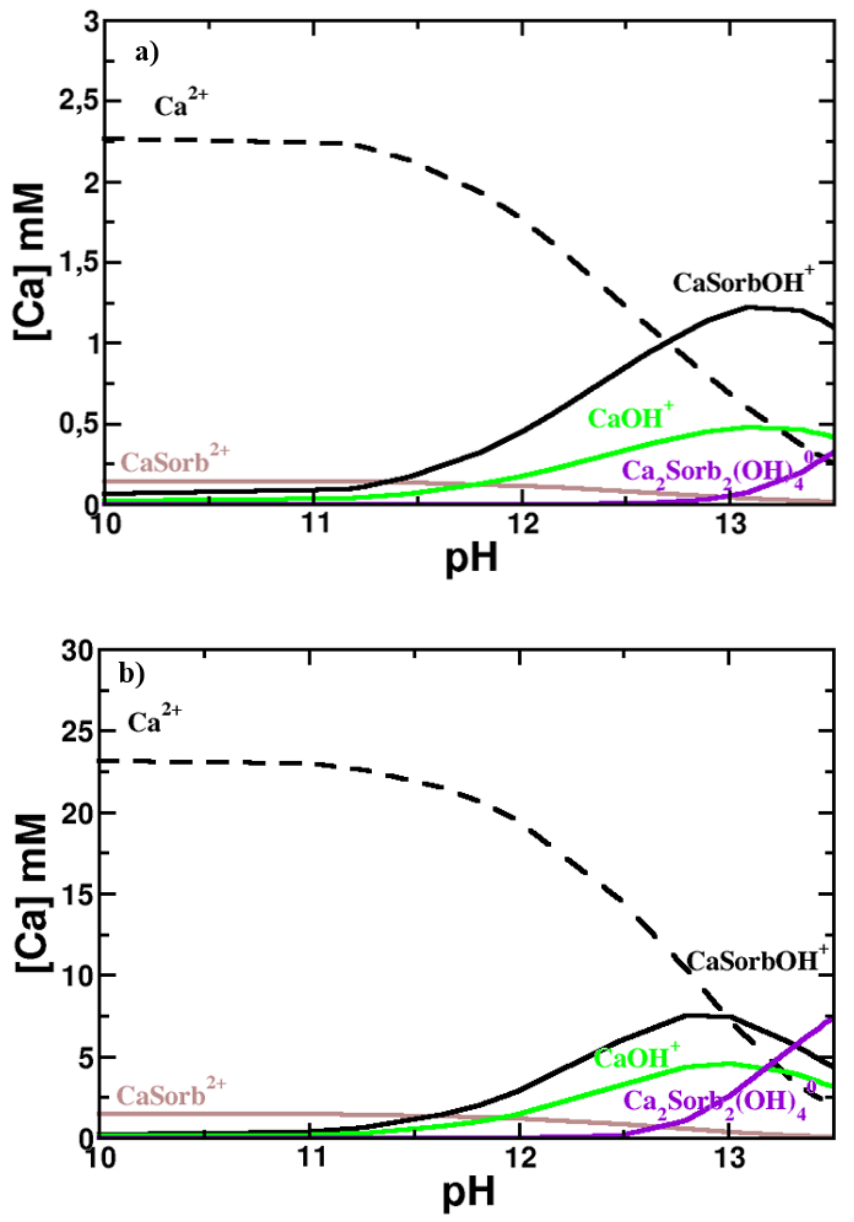

407 Figure 14: Calcium distribution (expressed as $\mathrm{mM} \mathrm{Ca}$ ) in a solution containing a) $2.5 \mathrm{mM}$ of $\mathrm{Ca}$, 408 b) $25 \mathrm{mM}$ of $\mathrm{Ca}$ and50 $\mathrm{mM}$ of sorbitol in the $\mathrm{pH}$ range 10 to 13.5 .

410 The observed tendency of calcium to form complexes with organics follows the order gluconate >>

411 sorbitol > mannitol > galactitol, which corresponds well with the tendency to sorb on portlandite 412 (see Supplementary informations) and C-S-H (18) (19): gluconate >> sorbitol > mannitol, but only 413 partially with their tendency to retard the $\mathrm{C}_{3} \mathrm{~S}$ hydration reported in Nalet and Nonat (15):

414 gluconate $>>$ sorbitol $>$ galactitol $>$ mannitol. The reason for the different sequence of galactitol and 415 mannitol on $\mathrm{C}_{3} \mathrm{~S}$ hydration is presently not clear. The charged gluconate, which complexed strongly 416 with calcium in solution had also the biggest retarding effect on $\mathrm{C}_{3} \mathrm{~S}$ hydration.

\section{Conclusions}


419 The complexation of $\mathrm{Ca}^{2+}$ with gluconate, D-sorbitol, D-mannitol and D-galactitol has been studied 420 via portlandite solubility measurement and titration experiments at low ionic strength $(0.1 \mathrm{M}$ $\left.421 \quad \mathrm{KNO}_{3}\right)$.

422 For gluconate, the multinuclear complexes already described in the literature allowed us to describe 423 the experimental data, after some further refinement of the complexation constants. At a pH of 12.5 424 and in the presence of portlandite the heteropolynuclear complex $\mathrm{Ca}_{3} \mathrm{Gluc}_{2}(\mathrm{OH})_{4}{ }^{0}$ dominates the 425 Ca-speciation, while at lower calcium concentrations $\mathrm{CaGluc}^{+}$(below pH 12) and $\mathrm{CaGlucOH}^{0}$ 426 (above $\mathrm{pH}$ 12) are the main complexes formed. This relative strong complex formation between 427 calcium and gluconate lowers concentrations of free $\mathrm{Ca}^{2+}$, which could contribute to a retardation of portlandite and C-S-H precipitation during cement hydration. The strong tendency of gluconate to form complexes with $\mathrm{Ca}$ reported here is consistent with the significant sorption of gluconate on $\mathrm{Ca}$ 430 on the surface of C-S-H and portlandite reported (19).

431 Sorbitol makes weaker complexes with calcium as observed both from portlandite solubility 432 measurements and titration results. Under all conditions studied, the predominant sorbitol complex 433 is the ternary $\mathrm{CaSorbOH}^{+}$complex, while the $\mathrm{CaSorb}^{2+}$ complex formed in negligible amounts 434 only. In all cases studied, $\mathrm{CaSorbOH}^{+}$complex had limited effect on calcium speciation below a $\mathrm{pH}$ 435 of 12 , but can dominate the calcium speciation at $\mathrm{pH} 12.5$ and above, at higher sorbitol 436 concentrations.

437 Similar observations have been made for D-mannitol and D-galactitol, which show an even weaker 438 tendency than sorbitol to form calcium complexes. Also for D-mannitol and D-galactitol only the 439 ternary $\mathrm{CaManOH}^{+}$and $\mathrm{CaGalOH}^{+}$complexes are relevant and they are expected to form mainly 440 above $\mathrm{pH} 12.5$ and at high mannitol and galactitol concentrations.

441 The observed tendency of calcium to form complexes follows the order gluconate $>>$ sorbitol $>$ 442 mannitol > galactitol, which corresponds well with the tendency to sorb on portlandite and C-S-H: 443 gluconate >> sorbitol > mannitol (19) but only partially with their tendency to retard the $\mathrm{C}_{3} \mathrm{~S}$ 444 hydration reported in (15): gluconate >> sorbitol > galactitol > mannitol. 


\section{Acknowledgements}

The financial support from Nanocem (core project 15) is thankfully acknowledged. We also would

like to thank the representatives of the industrial partners: L. Pegado, J.H. Cheung, V. Kocaba, P.

Juilland, and M. Mosquet for many helpful discussions and their interest in this project. We

sincerely thank L. Brunetti, S. El Housseini and D. Nguyen for their help in the laboratory work.

The use of the analytical platform of ISTerre, with the help of D. Tisserand, S. Bureau and S.

Campillo, is acknowledged.

\section{References}

\section{References}

1. Mann.S. Biomineralization: Principles and Concepts in Bioorganic Materials Chemistry. Oxford University Press, Oxford, New York. 2001.

2. Jolicoeur.C., Simard.M.A. Chemical admixture-cement interactions: phenomenology and physico-chemical concepts. Cement and Concrete Composites, 20(2-3), 87-101. 1998.

3. Young.J.F. A review of the mechanisms of set-retardation in portland cement pastes containing organic admixtures. Cement and Concrete Research, 2(4), 415-433. 1972.

4. Lorprayoon.V., Rossington.D.R. Early hydration of cement constituents with organic admixtures. Cement and Concrete Research, 11(2), 267-277. 1981.

5. Uchikawa.H., Hanehara.S., Shirasaka.T., Sawaki.D. Effect of admixture on hydration of cement, adsorptive behavior of admixture and fluidity and setting of fresh cement paste. Cement and Concrete Research, 22(6), 115-1129. 1992.

6. Jansen.D., Neubauer.J., Goetz-Neunhoeffer.F., Haerzschel.R., Hergeth.W.D. Change in reaction kinetics of a portland cement caused by a superplasticizer - Calculation of heat flow curves from XRD data. Cement and Concrete Research, 42(2), 327-332. 2012.

7. Cheung.J., Jeknavorian.A., Robert.L., Silva.D. Impact of admixtures on the hydration kinetics of Portland cement. Cement and Concrete Research, 41(12), 1289-1309. 2011.

8. Diamond.S. Interactions between cement minerals and hydroxycarboxylic-acid retarders: I, apparent adsorption of salicylic acid on cement and hydrated cement compounds. Journal of the American Ceramic Society, 54(6), 273-276. 1971.

9. Nelson.E.B. Cements additives and mechanisms of action. Well Cementing, 28, 3-1-3-37. 1990. 10. Milestone.N.B. Hydration of tricalcium silicate in the presence of lignosulfonates, glucose, and sodium gluconate. Journal of the American Ceramic Society, 62(8), 321-326. 1979.

11. Singh.N.B., Singh.S.P., Sarvehi.R. Effect of phenols on the hydration of Portland cement. Advances in Cement Research. 2(6), 43-48. 1989.

12. Zhang.L., Catalan.L.J.J., Balec.R.J., Larsen.A.C., Esmaeili.H.H. and Kinrade.S.D. Effect of saccharide set retarders on the hydration of ordinary portland cement and pure tricalcium silicate. Journal of the American Ceramic Society, 93 (1) 279-287. 2010.

13. Thomas.J.J., Jennings.H.M., Chen.J.J. Influence of nucleation seeding on the hydration mechanisms of tricalcium silicate and cement. Journal of Physical Chemistry, 113(11), 4327-4334. 2009. 
14. Pourchez.J., Grosseau.P., Ruot.B. Changes in $\mathrm{C}_{3} \mathrm{~S}$ hydration in the presence of cellulose ethers. Cement and Concrete Research, 40(2), 179-188. 2010.

488 15. Nalet.C., Nonat.A. Effects of hexitols on the hydration of tricalcium silicate. Cement and 489 Concrete Research, 91, 87-96. 2017.

490 16. Nalet.C., Nonat.A. Effects of functionality and stereochemistry of small organic molecules on the hydration of tricalcium silicate. Cement and Concrete Research, 87, 97-104. 2016. 17. Juilland.P., Gallucci.E. Hindered calcium hydroxide nucleation and growth as mechanism responsible for tricalcium silicate retardation in presence of sucrose. 329, 143-154. 2018.

18. Hansen, W. Actions of calcium sulfate and admixtures in portland cement pastes in "symposium on effect of water-reducing admixtures and set-retarding admixtures on properties of concrete". American Society for Testing Materials 3-37. 1960.

19. Nalet.C., Nonat.A. Ionic complexation and adsorption of small organic molecules on calcium silicate hydrate: relation with their retarding effect on the hydration of $\mathrm{C}_{3} \mathrm{~S}$. Cement and Concrete Research, 89, 97-108. 2016.

20. Singh.N.B. Influence of calcium gluconate with calcium chloride or glucose on the hydration of cements. Cement and Concrete Research, 5, 545-550. 1975.

21. Singh.N.B. Effect of gluconate on the hydration of cement. Cement and Concrete Research, 6 , 455-460. 1976.

22. Ma.S., Li.W., Zhang.S., Ge.D., Yu.J., Shen.X. Influence of sodium gluconate on the performance and hydration of portland cement. Construction and Building Materials, 91, 138-144. 2015.

23. Pallagi.A., Sebők.P., Forgó.P., Jakusch.T., Pálinkó.I., Sipos.P. Multinuclear NMR and molecular modelling investigations on the structure and equilibria of complexes that form in aqueous solutions of $\mathrm{Ca}^{2+}$ and gluconate. Carbohydrate Research, 345(13), 1856-1864. 2010. 24. Pallagi.A., Bajnóczi.É.G., Canton.S.E., Bolin.T., Peintler.G., Kutus.B.,Sipos.P. Multinuclear complex formation between $\mathrm{Ca}(\mathrm{II})$ and gluconate ions in hyperalkaline solutions.Environmental Science \& Technology, 48(12), 6604-6611. 2014.

25. Kutus.B., Ozsvár.D., Varga.N., Pálinkó.I., Sipos.P. ML and ML2 complexes forming between $\mathrm{Ca}(\mathrm{II})$ and D-glucose derivatives in aqueous solutions. Dalton Transactions, 46, 1065-1074. 2017. 26. Kutus.B., Gaona.X., Pallagi.A., Pálinkó.I., Altmaier.M., Sipos.P.,. Recent advances in the aqueous chemistry of the calcium(II)-gluconate system - Equilibria, structure and composition of the complexes forming in neutral and in alkaline solutions. Coordination Chemistry Reviews, 417, 213337. 2020.

27. Masone.M., Vicedomini.M. Gluconate and lactate as ligand of calcium ions. 71(9-10), 517-523. 1981.

28. Sawyer, D.T. Metal organic complexes. Chemical Reviews, 64(6), 633-643. 1964.

29. Haas.J.W. Complexation of calcium and copper with carbohydrates. Marine Chemistry, 19(4), 299-304. 1986.

30. Kieboom.A.P.C, Buurmans.H.M.A, Van Leeuwen.L.K., Van Benschop.H.J. Stability constants of (hydroxy)carboxylate and alditol-calcium(II) complexes in aqueous medium as determined by a solubility method. Journal of the Royal Netherlands Chemical Society, 98(6), 393-394. 1979. 31. Barthel.J., Jaenicke.R. Conway: Ionic Hydration in Chemistry and Biophysics: Studies in Physical and Theoretical Chemistry. Elsevier Scientific Publishing Company, 86(3), 264-264, Amsterdam and New York. 1982.

32. Parkhurst.D.L. PHREEQE: a computer program for geochemical calculations. U.S. Geological Survey, Water Resources Division, 80-96. 1981.

33. Ball.J.W., Nordstrom.D.K. User's Manual for WATEQ4F, with Revised Thermodynamic Data Base and Test Cases for Calculating Speciation of Major, Trace, and Redox Elements in Natural Waters. U.S. Geological Survey, 91-183, Washington DC. 1991.

34. Merkel.B., Planer-Friederich.B., Nordstrom.D. Groundwater Geochemistry. A Practical Guide to Modeling of Natural and Contaminated Aquatic Systems. Springer. 2005. 
537 35. Zhang.Z., Gibson.P., Clark.S.B., Tian.G., Zanonato.P.L., Rao.L. Lactonization and protonation 538 of gluconic acid: a thermodynamic and kinetic study by potentiometry, NMR and ESI-MS. Journal 539 of Solution Chemistry, 36(10), 1187-1200. 2007.

540 36. Bretti.C., Cigala.R.M., De Stefano.C., Lando.G., Sammartano.S. Acid-base and thermodynamic 541 properties of D-gluconic acid and its interaction with $\mathrm{Sn}^{2+}$ and $\mathrm{Zn}^{2+}$. Journal of Chemical and 542 Engineering Data, 61(6), 2040-2051. 2016.

37. Thoenen.T., Hummel.W., Berner.U., Curti.E., The PSI/Nagra Chemical Thermodynamic Data 